\title{
Hormone-responsive organoids from domestic mare and endangered Przewalski's horse endometrium
}

\author{
Riley E Thompson ${ }^{1,2}$, Aime K Johnson ${ }^{3}$, Pouya Dini ${ }^{4}$, Margherita Y Turco ${ }^{5}$, Tulio M Prado ${ }^{1}$, \\ Christopher Premanandan ${ }^{6}$, Graham J Burton $\mathbb{D}^{5}$, Barry A Ball $\mathbb{D}^{4}$, Brian K Whitlock ${ }^{1}$ and \\ Budhan S Pukazhenthi
}

\begin{abstract}
${ }^{1}$ Department of Large Animal Clinical Sciences, University of Tennessee, Knoxville, Tennessee, USA, ${ }^{2}$ Center for Species Survival, Smithsonian Conservation Biology Institute, Front Royal, Virginia, USA, ${ }^{3}$ Department of Clinical Sciences, Auburn University, Auburn, Alabama, USA, ${ }^{4}$ Department of Veterinary Science, University of Kentucky, Lexington, Kentucky, USA, ${ }^{5}$ Centre for Trophoblast Research, University of Cambridge, Cambridge, UK and ${ }^{6}$ Department of Veterinary Biosciences, The Ohio State University, Columbus, Ohio, USA
\end{abstract}

Correspondence should be addressed to B S Pukazhenthi; Email: pukazhenthib@si.edu

\begin{abstract}
The endometrium, the inner uterine lining, is composed of cell layers that come in direct contact with an embryo during early pregnancy and later with the fetal placenta. The endometrium is responsible for signals associated with normal reproductive cyclicity as well as maintenance of pregnancy. In the mare, functionally competent in vitro models of the endometrium have not been successful. Furthermore, the ability to study various reproductive processes in vitro may allow critical evaluation of signaling pathways involved in the reproductive diseases of animals that cannot be handled frequently, such as various wildlife species. Here we report the establishment of organoids, 3D structures, derived from fresh and frozen-thawed equine endometrium (Equus ferus caballus and E. f. przewalskii). Although organoids from domestic mares responded to exogenous hormonal stimuli, organoids from Przewalski's horse failed to respond to exogenous hormones. The present study represents a 'first' for any large animal model or endangered species. These physiologically functional organoids may facilitate improved understanding of normal reproductive mechanisms, uterine pathologies, and signaling mechanisms between the conceptus and endometrium and may lead to the development of novel bioassays for drug discovery.

Reproduction (2020) 160 819-831
\end{abstract}

\section{Introduction}

The endometrium of the equine uterus responds to hormonal stimulation throughout the estrous cycle by increasing progesterone and estrogen receptors during estrus (Hartt et al. 2005), stimulating proliferation of ciliated epithelial cells during diestrus, decreasing secretory cells during diestrus (Samuel et al. 1979), and by secreting prostaglandin $F_{2 \alpha}$ in response to oxytocin during luteolysis (Sharp et al. 1997, Starbuck et al. 1998, Stout et al. 2000, Santos et al. 2015, Annandale et al. 2018). Endometrial interactions with the embryo and with the placenta later in pregnancy are critical to produce live offspring. Development of an in vitro model system that mimics these physiological functions may facilitate studies focused on evaluation of normal physiological processes, signaling events during early pregnancy, and disease states that affect reproductive success (Collins et al. 2020). Previous attempts to develop an in vitro model for equine endometrium focused on monolayer cell cultures that are 2D and, thus, not normal conformationally, as the endometrium is a 3D structure (Szóstek et al. 2012a). Likewise, endometrial explant cultures were unable to support long-term growth in vitro (Schwinghamer et al. 2018). Recently, a co-culture system with equine endometrial epithelial and stromal cells utilizing welled plates with semipermeable membrane inserts was described, but there was poor epithelial cell differentiation and exogenous hormones failed to induce morphological changes or alter hormone receptor expression (Lapko et al. 2017). Therefore, other novel approaches are warranted to establish and maintain more structurally and physiologically normal endometrial cells in vitro.

Organoids represent 3D in vitro culture systems derived from stem or differentiated cells that can be cultured long-term and self-organize to mimic the structure and function of their tissue of origin (Clevers 2016). Typically, organoids are generated by embedding cells in an extracellular matrix, like Matrigel, and culturing them in media supplemented with various growth factors (Clevers 2016). Tissue-derived organoids 
have been established for many organs, including the intestines (Sato et al. 2011), liver (Huch et al. 2013), prostate (Karthaus et al. 2014), brain (Lancaster et al. 2013), and oviduct (Kessler et al. 2015, Xie et al. 2018). Endometrial organoids have been reported in the mouse and human using fresh endometrial tissues, which grow long-term (Boretto et al. 2017, Turco et al. 2017, Fitzgerald et al. 2019). We have therefore adapted this organoid methodology to derive endometrial organoids for the horse (domestic and non-domestic) to generate a much needed, physiologically relevant culture system that would allow the study of molecular mechanisms involved in normal physiologic processes of the equine endometrium, such as maternal recognition of pregnancy, and endometrial diseases (Collins et al. 2020). By evaluating these processes in vitro rather than in vivo, experiments can be better controlled, reduce dependence on live animals, and be performed throughout the year (using cryopreserved endometrial tissue) (Thompson et al. 2019). In this report, we describe the generation of hormonally-responsive organoids from fresh and cryopreserved endometrial explants derived from domestic (Equus ferus caballus) and Przewalski's (E. f. przewalskii) mares. The organoids retained their ability to maintain 3D tissue structure and responded to exogenous hormonal stimulation, providing a novel in vitro model for the endometrium in equids.

\section{Materials and methods}

\begin{abstract}
Animals
All animals were sampled using approved animal research protocols. The research herein described was reviewed and approved by the Smithsonian Conservation Biology Institute's Animal Care and Use Committee (Approval \#1811; Przewalski's mares), Auburn University, and University of Kentucky Animal Care and Use Committees (domestic mares). Experiments described were performed in accordance with relevant guidelines and regulations. Domestic horse mares were housed in outdoor paddocks with free access to grass or hay and ad libitum water. Mares were monitored daily by staff for medical concerns and treated appropriately as necessary.
\end{abstract}

\section{Collection of endometrial biopsies}

Endometrial biopsies were collected from adult domestic $(n=11)$ and Przewalski's mares $(n=3)$. Only mares with a Kenney-Doig score of I or Ila (Kenney \& Doig 1986) for endometrial biopsies, which controls for level of endometrial inflammation and fibrosis, were used in this study. Mares were evaluated for stage of the estrous cycle by transrectal ultrasound every other day, and endometrial biopsies were collected randomly from the body of the uterus during estrus ( $\geq 35 \mathrm{~mm}$ follicle diameter, no corpus luteum, and uterine edema). Przewalski's mares were confined to a padded hydraulic restraint device (Fauna Research Inc., Red Hook, NY, USA) and sedated with $15 \mathrm{mg}$ detomidine hydrochloride
IM (Dormosedan, Zoetis, Parsippany, NJ, USA) and $50 \mathrm{mg}$ butorphanol tartrate IM (Torbugesic, Zoetis) (Collins et al. 2012). Two endometrial biopsies were collected using aseptic techniques (Kenney \& Doig 1986) from each mare. Domestic mare biopsies were shipped in sterile saline overnight on ice to the Smithsonian Conservation Biology Institute (SCBI) for processing. Biopsies from Przewalski's mares were placed in sterile saline and processed within $2 \mathrm{~h}$ of biopsy collection.

\section{Tissue processing}

Unless stated otherwise, all chemicals were purchased from Sigma-Aldrich Chemicals, and all images were captured on an EVOS FL Auto 2 Imaging System.

Biopsies were dissected on ice with a sterile scalpel blade into 1-2 $\mathrm{mm}^{3}$ pieces in Handling Medium (HM; MEM with Earle's salts, $25 \mathrm{mM}$ HEPES, $100 \mathrm{U} / \mathrm{mL}$ penicillin, $0.1 \mathrm{mg} / \mathrm{mL}$ streptomycin, $0.1 \mathrm{mM}$ pyruvate, $2 \mathrm{mM}$ glutamax, 5\% BSA) (Thompson et al. 2019). Two small pieces were immediately fixed in $4 \%$ paraformaldehyde (Thermo Fisher Scientific) for histology and immunohistochemistry. Half of the remaining tissue pieces were cryopreserved, and the remaining tissue pieces were enzymatically dissociated for use in the culture system. Thus, the biopsies from each mare were used in both groups: organoids derived from fresh tissue and organoids derived from frozen-thawed tissue.

\section{Organoid culture}

Conditions for the generation of organoids were adapted from those described for human endometrial organoids (Boretto et al. 2017, Turco et al. 2017). Briefly, tissue pieces were incubated in collagenase $\mathrm{V}(0.4 \mathrm{mg} / \mathrm{mL}) /$ dispase II $(1.25 \mathrm{U} / \mathrm{mL})$ in RPMI-1640 medium for 20 min on a shaking warm plate at $37^{\circ} \mathrm{C}$. The tissue suspension was assessed every 10 min using an inverted microscope to confirm the presence of partially dissociated glands. The digest was then diluted in RPMI-1640 containing $20 \%$ fetal bovine serum to stop enzyme action. The solution was then passed through a $100-\mu \mathrm{m}$ cell strainer and then backwashed with RPMI-1640. The resulting suspension was centrifuged for $10 \mathrm{~min}$ at $1000 \mathrm{~g}$ at room temperature and the supernatant removed. The pellet was resuspended in $1 \mathrm{~mL}$ DMEM/F12 and centrifuged. The supernatant was discarded and the pellet suspended in 20X (v/v) phenol red free, growth factor reduced Matrigel (Corning). The Matrigel solution was plated in $25 \mu \mathrm{L}$ drops in a 48-well plate (Corning Costar TC-Treated Multiple Well Plates). The drops were allowed to solidify for $30 \mathrm{~min}$ at $37^{\circ} \mathrm{C}$. Then, $250 \mu \mathrm{L}$ organoid medium was added to each well (OM; DMEM/F12 without phenol red, 1\% penicillin/streptomycin, $2.5 \mathrm{mM}$ L-glutamine, 2\% B27 Plus (Thermo Fisher), 1\% N2 (Thermo Fisher), 1\% ITS, 1 $\mathrm{mM}$ nicotinamide, $50 \mathrm{ng} / \mathrm{mL}$ recombinant human EGF (R\&D Systems), $50 \mathrm{ng} / \mathrm{mL}$ recombinant human FGF-10 (PeproTech; Rocky Hill, NJ, USA), $100 \mathrm{ng} / \mathrm{mL}$ recombinant human Noggin (R\&D systems), $0.5 \mu \mathrm{M}$ TGF $\beta / A l k$ inhibitor A83-01 (Tocris; Minneapolis, MN, USA), $1.25 \mathrm{mM} \mathrm{N}$-acetyl-L-cysteine (Millipore Sigma), $10 \mu \mathrm{M}$ SB202190). The culture dishes were placed in an incubator at $37^{\circ} \mathrm{C}$ and $5 \% \mathrm{CO}_{2}$ in air. Half of the culture medium was removed and replaced every other day. 
The organoid cultures were passaged every 6 days. To passage, the Matrigel containing the organoids was scraped from the culture plate, placed in microcentrifuge tubes, and centrifuged at $1000 \mathrm{~g}$ for $10 \mathrm{~min}$. The supernatant was removed, and the pellet was resuspended in DMEM/F12. The organoids were further dissociated by repeated pipetting ( 800x), washed twice in DMEM/F12, and replated as previously described following resuspension in Matrigel.

After the second passage (18 days from initial isolation of endometrial glands), exogenous hormones were added to the culture medium. Briefly, there were six treatment groups: no hormones added to culture medium (control, C) for 6 days, $1 \mu \mathrm{M}$ progesterone for 6 days $\left(\mathrm{P}_{4}\right), 10 \mathrm{nM}$ estradiol- $17 \beta$ for 6 days $\left(E_{2}\right), 10 \mathrm{nM}$ estradiol- $17 \beta$ for 2 days followed by one $\mu \mathrm{M}$ progesterone for 4 days $\left(E_{2} / P_{4}\right)$, control medium for 5 days then $10^{-5} \mathrm{M}$ oxytocin for $24 \mathrm{~h}$ (C/OT-5), and control medium for 5 days then $10^{-6} \mathrm{M}$ oxytocin for $24 \mathrm{~h}$ (C/OT-6). All experiments were repeated eight times for each of the hormonal treatments per mare. Organoids were removed from culture after hormonal treatments and processed for subsequent analyses (see histology, gene expression, immunohistochemistry, and transmission electron microscopy ).

\section{Organoid generation from single cells}

Endometrial glands were dissociated as previously described, and then the cell suspension was filtered through a $40 \mu \mathrm{m}$ cell strainer to ensure only single cells were obtained. Isolated cell suspension was serially diluted to obtain 5.2 cells/ $\mu \mathrm{L}$. Then cells were plated (26 cells per $5 \mu \mathrm{L}$ droplet of Matrigel with three droplets per well; 2500 total single cells in 32 wells), overlaid with $250 \mu \mathrm{L}$ of OM, and cultured for 14 days as described previously.

\section{Tissue cryopreservation and thawing}

Cryopreservation was performed as previously described (Thompson et al. 2019). Briefly, explants were cryopreserved in $10 \%(\mathrm{v} / \mathrm{v})$ DMSO in MEM with Earle's salts containing 25 $\mathrm{mM}$ HEPES, $100 \mathrm{U} / \mathrm{mL}$ penicillin, $0.1 \mathrm{mg} / \mathrm{mL}$ streptomycin, 0.1 $\mathrm{mM}$ pyruvate, $2 \mathrm{mM}$ Glutamax, and 20\% (v/v) fetal bovine serum. Three cryovials per individual mare were used. Nine to ten pieces of tissue were placed in each cryovial containing $0.5 \mathrm{~mL}$ of the freezing media. The cryovials were placed in a $-80^{\circ} \mathrm{C}$ freezer in Cool Cell Freezing Containers (Biocision; Larkspur, CA, USA; temperature decrease $\sim 1^{\circ} \mathrm{C}$ per minute) overnight. On the second day, the cryovials were plunged into liquid nitrogen and stored until thawing.

To thaw, cryovials were removed from liquid nitrogen and thawed in room temperature air $\left(22^{\circ} \mathrm{C}\right)$ for one minute and then immersed in a $25^{\circ} \mathrm{C}$ water bath for one minute (Pukazhenthi et al. 2015, Thompson et al. 2019). Then $1 \mathrm{~mL}$ of thawing medium (TM; MEM with Earle's salts containing $25 \mathrm{mM}$ HEPES, $100 \mathrm{U} / \mathrm{mL}$ penicillin, $0.1 \mathrm{mg} / \mathrm{mL}$ streptomycin, $0.1 \mathrm{mM}$ pyruvate, $2 \mathrm{mM}$ glutamax, $20 \%$ fetal bovine serum) was added at room temperature and mixed gently for $1 \mathrm{~min}$. The contents of the vial were then poured into a petri dish containing $5 \mathrm{~mL}$ TM to dilute the DMSO and incubated for 5 min. This step was repeated twice more, and tissue pieces then were enzymatically digested for organoid culture, as described above.

\section{Histology}

Organoids were soaked in Cell Recovery Solution (Corning) and washed with DMEM/F12 via centrifugation (600 $g$ for 6 min). Organoid pellets were fixed in $4 \%$ paraformaldehyde for $30 \mathrm{~min}$, then embedded in 2\% agarose gel (Bio-Rad). The agarose-embedded organoids were stored in $70 \%$ ethanol until processing. The organoids were embedded in paraffin wax, sectioned $(6 \mu \mathrm{m})$, and stained with hematoxylin and eosin stain using standard procedures.

\section{Gene expression}

Organoid pellets were formed as for histology preparation above but were flash frozen in liquid nitrogen and stored at $-20^{\circ} \mathrm{C}$ until processing, rather than fixed. Qiagen RNeasy Micro Kit (Qiagen Sciences Inc.) was used to extract total RNA and analyzed for quantity and quality (260/280 and 260/230 ratios) using a NanoDrop spectrophotometer (Thermo Scientific). Oligo(dT) primers $(0.5 \mu \mathrm{g})$ for mRNA and Superscript III reverse-transcriptase were used to synthesize cDNA with SuperScript III First-Strand Synthesis System (Invitrogen). CDNA was reverse transcribed with 500 ng total RNA for use in prostaglandin-endoperoxide synthase 2 (PTGS2), prostaglandin E synthase (PGES), and oxytocin receptor (OXTR) reactions and $200 \mathrm{ng}$ total RNA for the remaining reactions. Quantitative real time PCR (qPCR; Light Cycler 96, Roche) was then utilized to assess mRNA expression with FastStart Essential DNA Green Master kit (Roche). Two microliters cDNA, $1 \mu \mathrm{L}$ forward primer $(0.5 \mu \mathrm{M}), 1 \mu \mathrm{L}$ reverse primer $(0.5 \mu \mathrm{M}), 6 \mu \mathrm{L}$ water, and $10 \mu \mathrm{L}$ DNA Green Master were used in each PCR reaction, and all reactions were performed in duplicate. PCR conditions included $95^{\circ} \mathrm{C}$ for $10 \mathrm{~min}$, followed by 45 cycles of $95^{\circ} \mathrm{C}$ for $10 \mathrm{~s}, 55^{\circ} \mathrm{C}$ for $10 \mathrm{~s}$, and $72^{\circ} \mathrm{C}$ for $10 \mathrm{~s}$. Specificity of amplified products was assessed by examining the melting curve for each transcript. Specifically, we assessed MKI67 for cell proliferation, estrogen receptor- $\alpha$ (ESR1), progesterone receptor $(P G R)$, E-cadherin $(C D H 1)$ for cell adhesion, PTGS2, $P G E S$, and OXTR. The reference gene GAPDH was used to normalize gene expression using the $2^{-\triangle \Delta C T}$ method (Livak \& Schmittgen 2001). Primers used for gene expression analysis are summarized in Table 1.

\section{Immunohistochemistry}

Tissue sections previously embedded in paraffin were mounted on Superfrost Plus slides. Sections were incubated in a series of Slide Brite (Thermo Fisher) washes to remove paraffin and then rehydrated by immersing the slides in a series of ethanol washes. Antigen retrieval was accomplished by incubating the slides in $10 \mathrm{mM}$ sodium citrate buffer at $96^{\circ} \mathrm{C}$ for $20 \mathrm{~min}$. Then sections were incubated in blocking serum (RTU Vectastain kit; Vector Laboratories; Burlingame, CA, USA) for 20 min. Primary antibodies were diluted in $0.1 \%$ Tween 20, 1\% BSA, and PBS (Table 2). For negative control, sections were incubated with $0.1 \%$ Tween $20,1 \%$ BSA, and PBS alone. All slides were 
Table 1 Primer sequences used in gene expression analysis.

\begin{tabular}{|c|c|c|c|c|}
\hline \multirow[b]{2}{*}{ Primers } & \multirow[b]{2}{*}{ Reference } & \multicolumn{2}{|c|}{ Sequences } & \multirow[b]{2}{*}{ bp } \\
\hline & & Forward & Reverse & \\
\hline $\mathrm{CDH1}$ & Thompson et al. (2019) & GAGTTTTGAAGGATGCACTG & TCATCTCCGGATTATGAAGC & 125 \\
\hline MKI67 & Thompson et al. (2019) & TCCTTGTGCAAGAGTGGCTT & ССССGСТССТTTTGATGGTA & 136 \\
\hline ESR1 & Thompson et al. (2019) & CGAGGCTTCCATGATGGGTT & AGGATCTCTAGCCAGGCACA & 147 \\
\hline$P G R$ & Perrini et al. (2016) & GTCAGTGGACAGATGCTGTA & CGCCTTGATGAGCTCTCTAA & 255 \\
\hline PTGS2 & Szóstek et al. (2012b) & GCCACGATTTGGCTGCGGGA & ССTGCTCGTCTGGAACAAGCGT & 96 \\
\hline PGES & Szóstek et al. (2012b) & CACGCTGCTGGTCATCAAGA & СТСТCAGGCAACGСТССАС & 152 \\
\hline OXTR & Rebordão et al. (2017) & TGGACGCCATTCTTCTTCGT & GCCCGTGAACAGCATGTAGA & 141 \\
\hline GAPDH & Thompson et al. (2019) & GTTTGTGATGGGCGTGAACC & TTGGCAGCACCAGTAGAAGC & 255 \\
\hline
\end{tabular}

incubated overnight at $4{ }^{\circ} \mathrm{C}$. Endogenous peroxidase activity was neutralized with $0.3 \% \mathrm{H}_{2} \mathrm{O}_{2}$ for $15 \mathrm{~min}$. Then the biotinylated horse anti-mouse or anti-rabbit secondary antibody was added to each slide (RTU Vectastain kit; Vector Laboratories) for 30 min and visualized using Vectastain $A B C$ and $D A B$ substrate solution (DAB substrate kit; Vector Laboratories). All slides were then counterstained with hematoxylin. Expression of estrogen receptor $\alpha$ (ESR1; Kalpokas et al. 2010) and progesterone receptor (PGR) proteins established whether treatments caused organoids to change in response to sex steroid stimulation (Hartt et al. 2005). PTGS2, an enzyme that causes the production of prostaglandins, was assessed to determine response to oxytocin treatment (Keith et al. 2013).

\section{Periodic acid Schiff (PAS) staining}

PAS stains mucin and has been used as a method of evaluating functionality (mucin production) of organoids (Boretto et al. 2017). Similar to the immunohistochemical staining above, fixed, embedded, and deparaffinized sections of organoids were incubated in periodic acid solution and Schiff reagent. The sections were then counterstained with hematoxylin, dehydrated, and mounted.

\section{Transmission electron microscopy}

Organoid pellets were generated as for histology preparation above but were fixed in $2 \%$ glutaraldehyde and $4 \%$ paraformaldehyde in $0.1 \mathrm{M}$ cacodylate buffer. Sample preparation and imaging with a JEOL 1230 transmission electron microscope was conducted by the University of Virginia Advanced Microscopy Facility.

\section{Viability staining}

Viability of organoids was assessed using SYBR-PI (Garner \& Johnson 1995). Briefly, $20 \mu \mathrm{M}$ SYBR-14 (LIVE/DEAD Sperm Viability Kit; Molecular Probes) was added to each well containing a $25 \mu \mathrm{L}$ Matrigel droplet in $250 \mu \mathrm{L}$ OM. Samples were incubated for $15 \mathrm{~min}\left(37^{\circ} \mathrm{C}\right)$ and then $48 \mu \mathrm{M}$ propidium iodide (LIVE/DEAD Sperm Viability Kit) was added to each well. All samples were further incubated for an additional $90 \mathrm{~min}$ to facilitate uptake of stain before imaging. Cells staining green were considered viable (membrane intact) and cells staining red were considered non-viable (non-intact membrane) for qualitative analysis.

\section{Statistical analysis}

Gene expression data were analyzed in the statistical program R (R Core Team 2014). A Shapiro-Wilk test determined that gene expression data were not normally distributed. Therefore, Kruskal-Wallis test was used to assess significance and followed by a post hoc Dunn test. Values are presented in box plots as mean \pm S.E.M.. A $P$-value of $<0.05$ was used to determine statistical significance compared to $C$ treatment.

\section{Results}

\section{Endometrial organoids can be established from both fresh and frozen-thawed domestic mare tissue biopsies}

Endometrial organoids derived from both fresh and frozen-thawed domestic mare explants $(n=11$; samples from all 11 mares were used both fresh and frozen-thawed) were grown for 24 days (three passages, 6 days per passage; Fig. 1A and B) before removing organoids from culture conditions. Live/dead staining with SYBR-14 and propidium iodide revealed organoids composed of predominantly viable cells (Fig. 1C). A small proportion of organoids ( $5 \%$ of the total organoids generated across all individual mares) also revealed some degenerative changes, as evidenced by dark coloration of cells evaluated by microscopy. Histologic assessment of organoids revealed cystic structures composed of columnar epithelial cells with

Table 2 Summary of primary antibodies used for immunohistochemistry analysis.

\begin{tabular}{|c|c|c|c|c|}
\hline Primary antibody & Host & Type & Dilution & Source \\
\hline ESR1 & Mouse & Monoclonal & $1: 200$ & Santa Cruz Biotechnology; sc-787 \\
\hline PGR & Mouse & Monoclonal & $1: 200$ & ThermoFisher Scientific; MA5-12642 \\
\hline PTGS2 & Rabbit & Polyclonal & $1: 25$ & Oxford Biomedical Research; PG46 \\
\hline
\end{tabular}




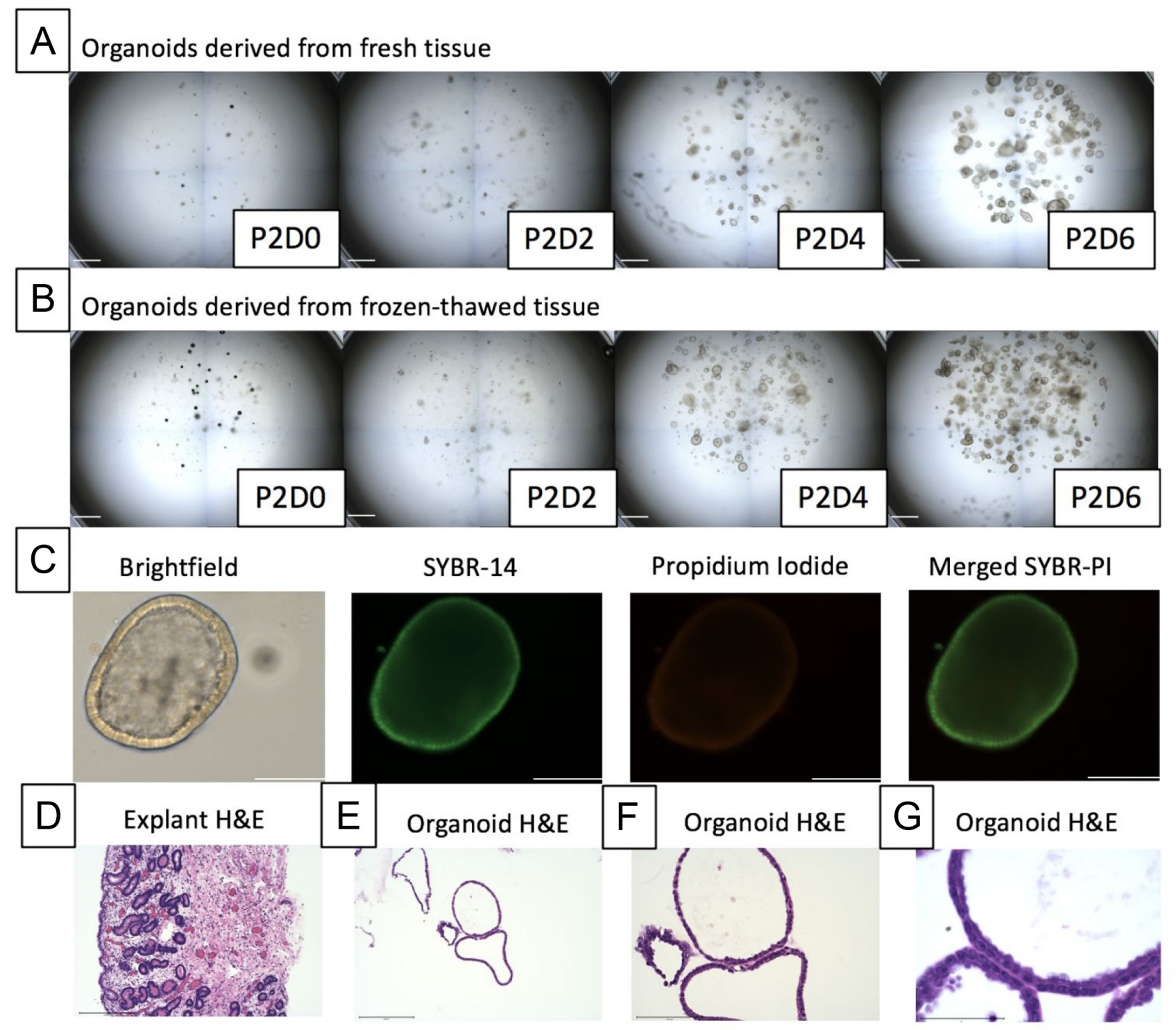

Figure 1 Establishment of organoids from fresh and cryopreserved equine endometrial tissues. (A and B) Representative culture images of organoids derived from fresh (A) and frozen-thawed (B) domestic mare endometrial tissue through passage 2 days $0-6$. (C) Viability staining of a single organoid in culture using SYBR-14 and propidium iodide staining. (D, E, F and G) Histological images of intact explant (D) and organoids (E, F and G). P, passage and D, day of culture. Scale bar $=1000 \mu \mathrm{m}(\mathrm{A}$ and B), $200 \mu \mathrm{m}(\mathrm{C}, \mathrm{D}$ and $\mathrm{E}), 100 \mu \mathrm{m}(\mathrm{F})$, and $25 \mu \mathrm{m}(\mathrm{G})$.

basally located nuclei (Fig. 1E, F and G) consistent with intact endometrial explant gland histology (Fig. 1D). Transmission electron microscopy (TEM) revealed wellorganized microvillus columnar epithelial cells with extensive network of secretory apparatus (Fig. 2A, B, C and D). Secretory function was further demonstrated with PAS stain revealing mucin production by equine endometrial organoids (Fig. 3). Furthermore, single cells derived from intact endometrial glandular fragments retained their clonogenic ability in vitro, as demonstrated by single cells developing into 3D organoids, albeit at a very low rate (24 organoids/2500 single cells; $0.1 \%$; data not shown).

\section{Organoids respond to exogenous hormonal stimuli}

Gene expression of organoids derived from both fresh and frozen-thawed tissue explants was altered in response to exogenous hormone treatments, which is necessary to determine whether organoids mimic the endometrium in vivo (via mounting a physiological response to estrogen, progesterone, and oxytocin). $\mathrm{CDH1}$, a marker for cell adhesion, was reduced in frozen-thawed explantderived organoids in response to $10 \mathrm{nM}$ estradiol-17 $\beta$ for 2 days followed by $1 \mu \mathrm{M}$ progesterone for 4 days $\left(\mathrm{E}_{2} / \mathrm{P}_{4} ; P=0.01\right), 1 \mu \mathrm{M}$ progesterone for 6 days $\left(\mathrm{P}_{4}\right.$; $P=0.02$ ), and control medium for 5 days then $10^{-5} \mathrm{M}$ 


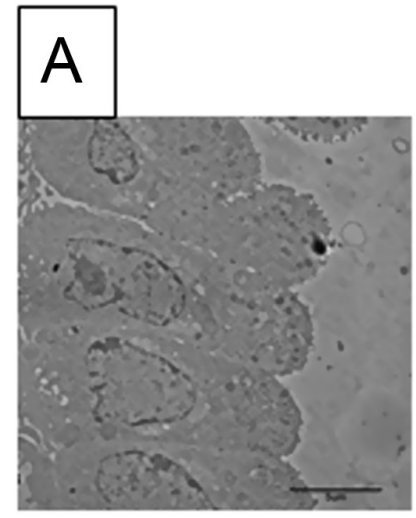

Fresh

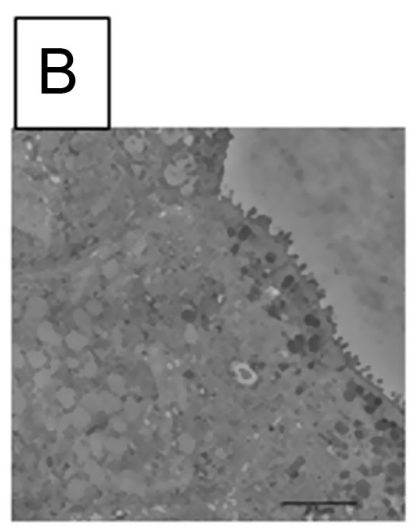

Fresh

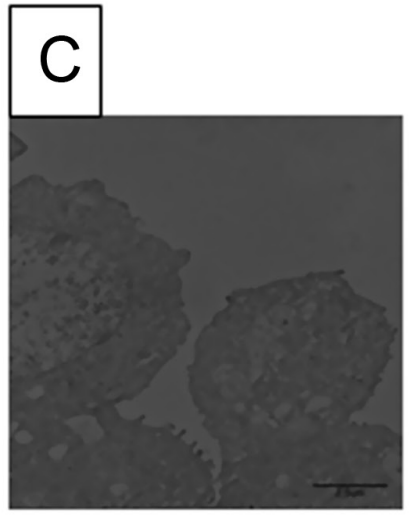

Frozen-thaw

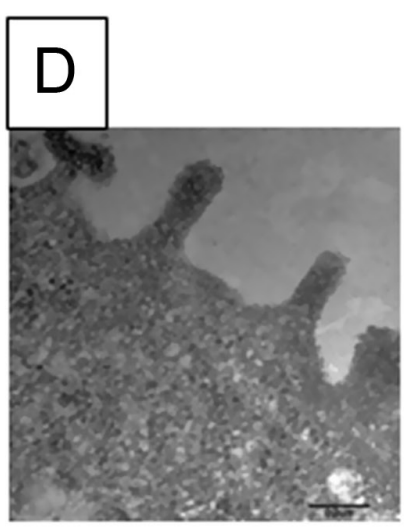

Frozen-thaw

Figure 2 In vitro produced organoids retain structural organization of endometrial glands from intact tissues. Representative transmission electron microscopy images of $C$ treatment groups for organoids derived from both fresh $(A$ and $B)$ and frozen-thawed (C and D) domestic mare endometrial tissue. Scale bar $=5 \mu \mathrm{m}(\mathrm{A}), 2.5 \mu \mathrm{m}$ (B and C), $0.2 \mu \mathrm{m}(\mathrm{D})$.

oxytocin for $24 \mathrm{~h}(\mathrm{C} / \mathrm{OT}-5 ; P=0.02)$ compared to control (C, no hormones added; Fig. 4A). No differences were detectable in MKI67 expression for either fresh $(P=0.054)$ or frozen-thawed $(P=0.14)$ explant-derived organoids compared to C (Fig. 4B). Expression of ESR1 was reduced in both fresh and frozen-thawed organoids compared to $C$ for organoids treated with both $10 \mathrm{nM}$ estradiol-17 $\beta$ for 6 days $\left(\mathrm{E}_{2} ; P=0.002\right.$ and $P=0.002$, respectively) and $\mathrm{E}_{2} / \mathrm{P}_{4} \quad(P=0.009$ and $P=0.001$, respectively; Fig. 4C). $P G R$ gene expression in fresh tissue-derived organoids was increased compared to $\mathrm{C}$ for $\mathrm{E}_{2}$ organoids $(P=0.01$; Fig. 4D).

We also evaluated PTGS2, PGES, and OXTR gene expression in response to treatment with two concentrations of oxytocin $\left(10^{-5} \mathrm{M}\right.$ and $\left.10^{-6} \mathrm{M}\right)$ to further evaluate cellular function. Previous reports indicated that prostaglandin production in response to oxytocin treatment is a reliable method to confirm that cultured endometrial cells exhibit normal physiological function (Takahashi et al. 2001, Szóstek et al. 2012a). Expression of PTGS2 (Fig. 4E) was elevated in fresh tissue-derived organoids treated with control medium for 5 days then $10^{-6} \mathrm{M}$ oxytocin for $24 \mathrm{~h}$ (C/OT-6) compared to $\mathrm{C}(P=0.004)$ and reduced in frozen-thawed explantderived organoids treated with C/OT-5 compared to C $(P=0.003)$. Levels of PGES were elevated in both fresh and frozen-thawed tissue-derived explants treated with C/OT-6 compared to $\mathrm{C}(P=0.014$ and $P=0.017$, respectively; Fig. 4F). OXTR expression (Fig. 4G) was reduced in fresh tissue-derived organoids treated with C/OT-5 compared to C $(P=0.008)$ with no differences among treatments for frozen-thawed explant-derived organoids $(P=0.87)$. Direct comparison of fresh and frozen-thawed explant-derived organoids revealed differences for CDH1 $(P=0.0006)$, MKI67 $(P=0.048)$, and PTGS2 $(P=0.005)$ with no differences for ESR1 $(P=0.984), P G R(P=0.095), P G E S(P=0.764)$, or OXTR $(P=0.301)$.

Immunohistochemistry revealed that expression of ESR1 and PGR was localized to the nuclei of both fresh and frozen-thawed explant-derived organoids (Fig. 5A, $B$ and D). Expression of PTGS2 was localized to the cytoplasm of both fresh and frozen-thawed explantderived organoids (Fig. 5C and D).
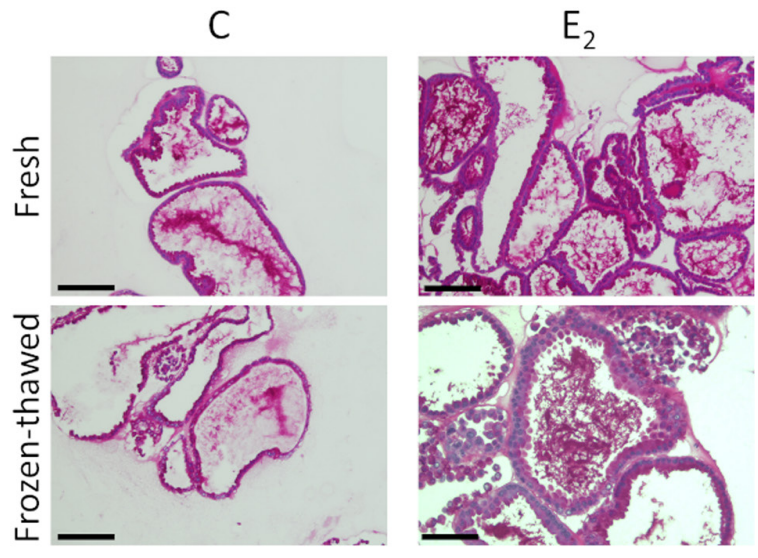

Reproduction (2020) $160819-831$

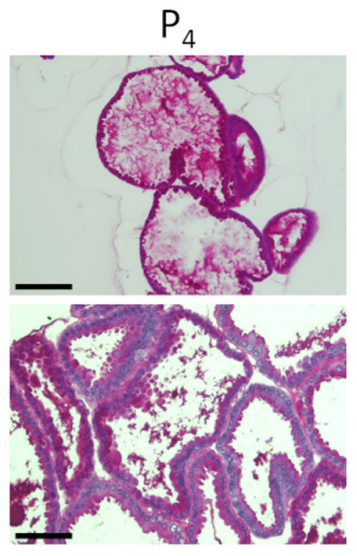

Figure 3 Equine endometrial organoids secrete mucin. Representative periodic acid Schiff (PAS) staining of fresh and cryopreserved tissue-derived organoids from domestic mares for $C, E_{2}$, and $P_{4}$ treatment groups. Scale bar $=100 \mu \mathrm{m}$. 

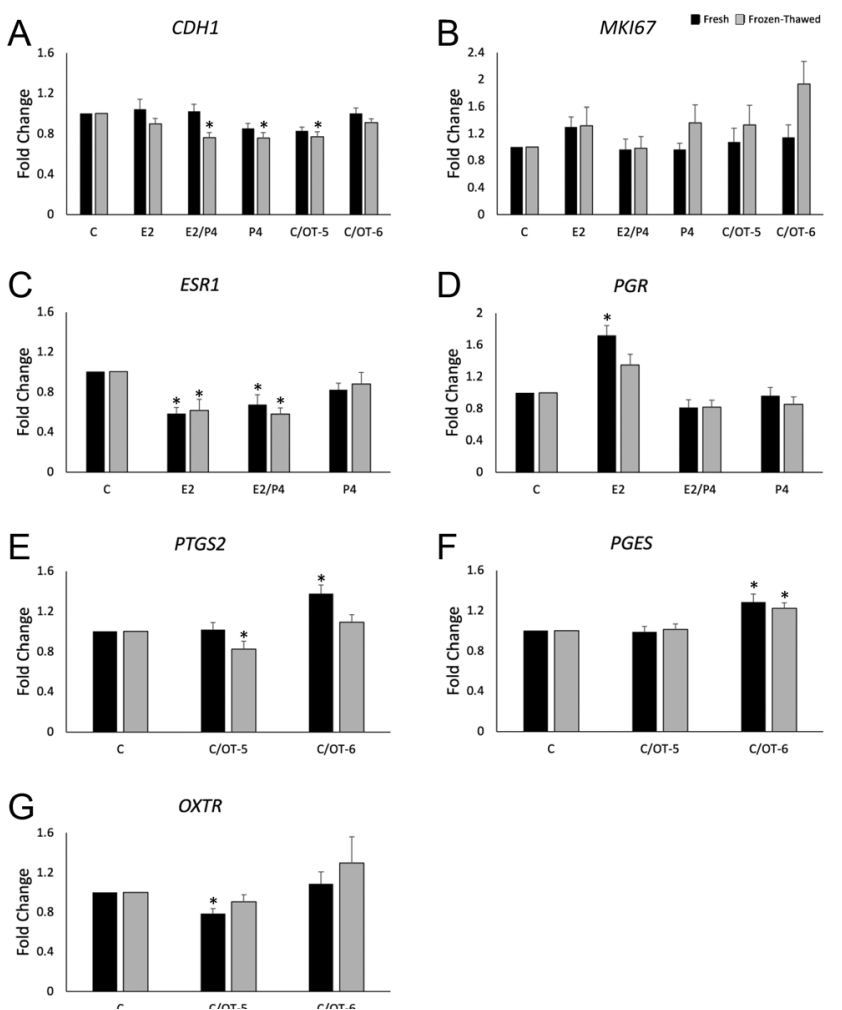

Figure 4 In vitro produced endometrial organoids retain the ability to respond to exogenous hormones. Gene expression of $E$-cadherin (A), Ki67 (B), ESR1 (C), PGR (D), PTGS2 (E), PGES (F), and OXTR (G) in organoids derived from fresh and frozen-thawed domestic mare endometrial tissue $(n=11)$. Asterisks represent significant differences among fresh tissue-derived organoid treatments compared to the fresh tissue-derived organoid $\mathrm{C}$ and frozen-thawed tissue-derived organoid treatments compared to the frozen-thawed tissue-derived organoid C.

\section{Endometrial organoids derived from Przewalski's mare biopsies proliferate and respond to hormonal stimulation in vitro}

Using our now established domestic mare endometrial organoid culture conditions, we set out to establish organoids from frozen-thawed explants from Przewalski's mares ( $n=3$; Fig. 6A). Gene expression among treatment groups compared to $C$ was not different for ESR1 $(P=0.125), P G R(P=0.143), C D H 1$ $(P=0.349)$, MKI67 $(P=0.664), P T G S 2(P=0.240), P G E S$ $(P=0.661)$, or OXTR $(P=0.725$; data not shown). Direct comparison of Przewalski's horse to domestic horse organoids showed elevated OXTR $(P=0.006)$ in the Przewalski's horse but no difference for ESR1 $(P=0.689)$, $P G R(P=0.486), C D H 1(P=0.104), M K I 67(P=0.090)$, PTGS2 $(P=0.811)$, or PGES $(P=0.099)$. Similar to the domestic horse, immunohistochemistry of ESR1 and PGR revealed expression localized to the nuclei of organoids and PTGS2 expression in the organoid cytoplasm (Fig. $6 \mathrm{~B}, \mathrm{C}$ and $\mathrm{D})$.

\section{Discussion}

Here we report the first successful generation of organoids derived from fresh and frozen-thawed endometrial tissues from domestic and non-domestic equids. Results also represent a 'first' for any domestic large animal or wildlife model. All organoids maintained structural characteristics of the original tissue forming cystic structures lined with microvillus columnar cells with basally located nuclei. Organoids derived from both fresh and frozen-thawed endometrial tissues from domestic mares expressed a modest response to exogenous hormones. In the present study, cultures were ended after 24 days (three passages) to ensure a consistent growth period and facilitate subsequent experimentation. However, additional studies are warranted to understand the impact of longer culture periods on endometrial organoid viability and function. Formation of organoids required inclusion of an extracellular matrix, Matrigel. Furthermore, these 3D structures responded to external hormonal stimuli, a necessary feature for mimicking in vivo function. Interestingly, culture conditions similar to those previously described for murine and human endometrial organoids were able to generate endometrial organoids from both domestic and non-domestic equids. This further suggests that mechanisms involved in the formation of organoids in vitro from endometrial tissues may be conserved among the laboratory mouse, human, and equine models.

While mouse endometrial organoids have been reported to be either 'dense' or 'cystic (Boretto et al. 2017), both human and horse endometrial organoids appear as discrete, cystic structures lined by columnar epithelial cells (Boretto et al. 2017, Turco et al. 2017). Though the clonogenic rate was low, the rate reported in human endometrial organoids was only $2-4 \%$ in cells plated with 100 cells per $5 \mu \mathrm{L}$ drop of Matrigel and 10 times lower in cells plated with 10 cells per $5 \mu \mathrm{L}$ drop (Turco et al. 2017). Estimation of clonogenic rate in the equine endometrial organoids used 26 cells per $5 \mu \mathrm{L}$ Matrigel drop for a rate of $0.1 \%$. As the human endometrium is sloughed and regenerated every month through the menstrual cycle, a higher clonogenic rate in endometrial cells is expected than in equids that experience estrous cycles which do not involve endometrial sloughing. Furthermore, the addition of specific supplements to culture medium, such as the Glycogen Synthase Kinase-3 inhibitor CHIR9902 or Rho-associated protein kinase (ROCK) inhibitors, may improve clonogenic rate of cells cultured in a low density (Watanabe et al. 2007, Koyanagi et al. 2008, Ying et al. 2008, Li et al. 2009, Huang et al. 2011). Transmission electron microscopy revealed basally located nuclei, apical microvilli, and a well-formed secretory apparatus in the equine endometrial organoids, demonstrating that the organoids appear to retain their secretory function similar to in vivo endometrium. Moreover, qualitative immunohistochemistry revealed the presence of ESR1, PGR, and PTGS2 proteins, indicating the equine 

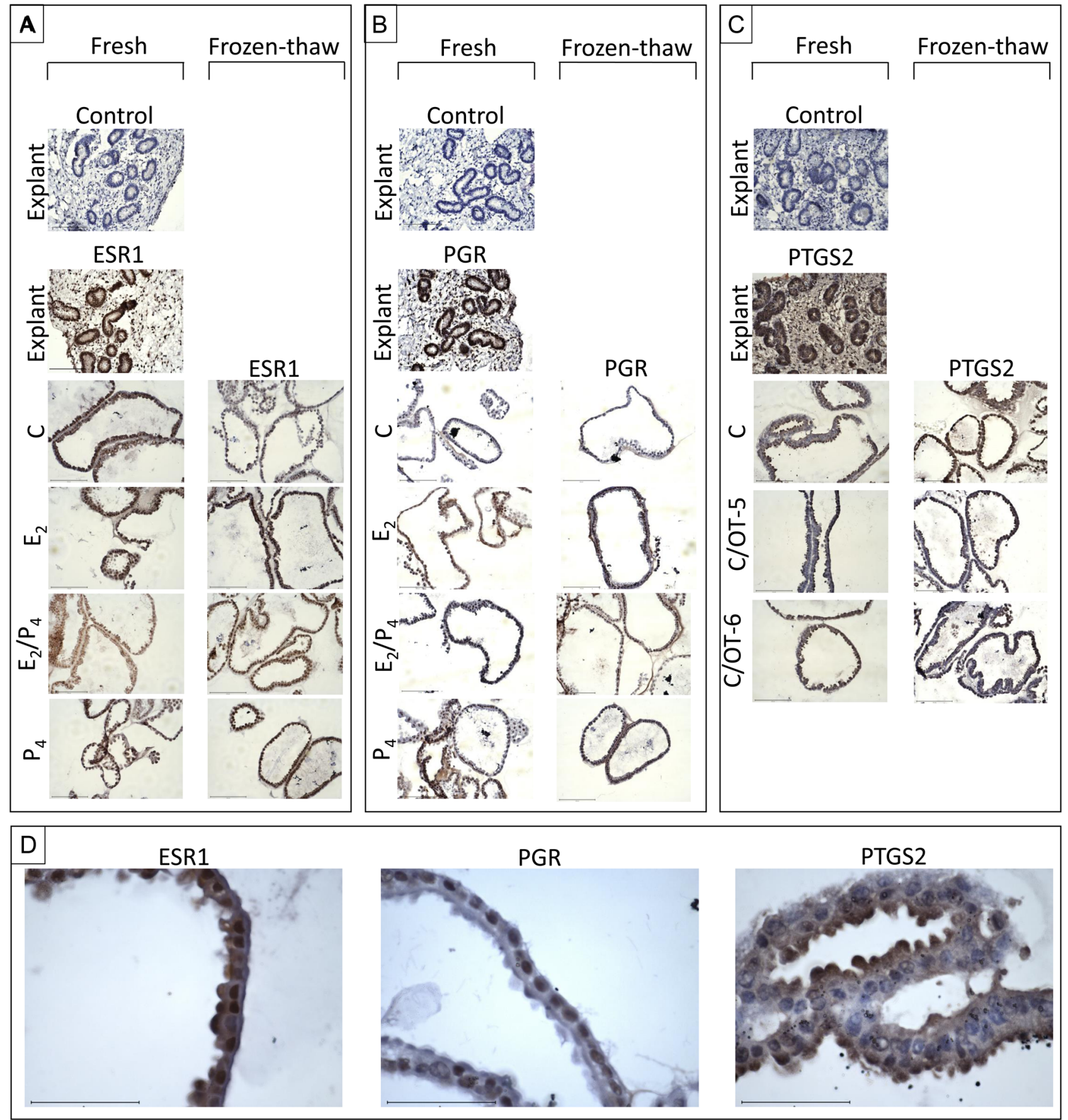

Figure 5 Endometrial tissues and organoids express ESR1, PGR, and PTGS2 proteins. Representative immunohistochemistry of fresh tissue and fresh and cryopreserved tissue-derived organoids from domestic mares evaluated for expression of ESR1 (A), PGR (B), PTGS2 (C), and a higher magnification (1000X) of fresh Control organoids stained for ESR1, PGR, and PTGS2 (D). Scale bar $=100 \mu \mathrm{m}$ (A, B and C) and $25 \mu \mathrm{m}$ (D).

organoids are capable of responding to exogenous hormonal stimuli.

Culture media used here varied slightly from those reported for human endometrial organoids. The media used for equine organoids was most similar to the report by Boretto et al. (2017) with the primary difference that the Wnt activator R-spondin-1 was not used in the equine organoid medium, and estradiol- $17 \beta$ was not used during expansion of the equine organoids, as this reduced rate of organoid expansion (data not shown). When compared to the culture medium used by Turco et al. (2017), several supplements, including primocin, recombinant human R-spondin-1, and recombinant human hepatocyte growth factor (HGF), were not used during equine endometrial 

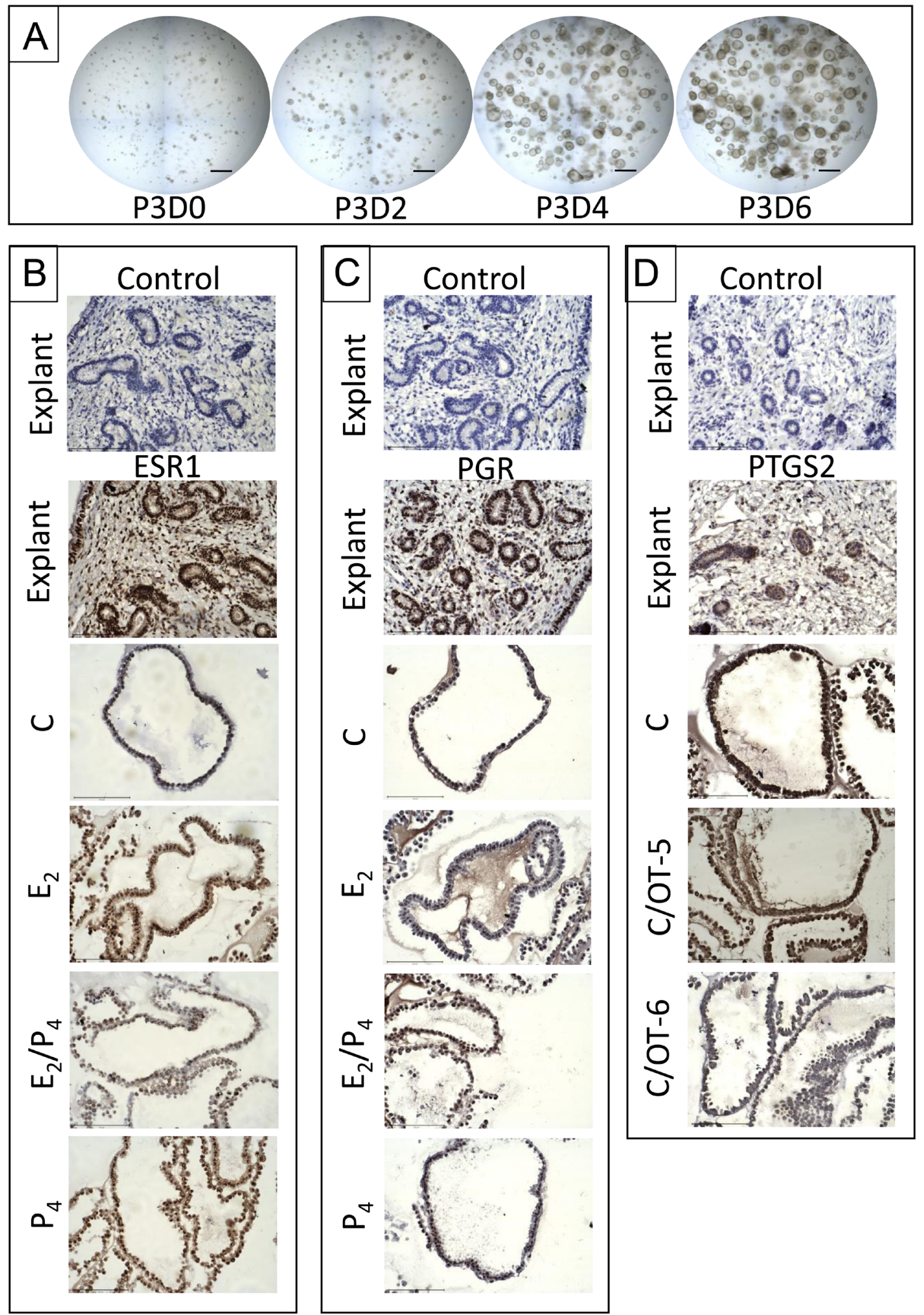

Figure 6 Establishment of endometrial organoids from the endangered Przewalski's horse and expression of ESR1, PGR, and PTGS2 proteins in tissue and organoids. (A) Representative culture images of organoids derived from frozen-thawed Przewalski's mare endometrial tissue through passage 3 days 0-6. (B, C and D) Immunohistochemistry of Przewalski's mare organoids evaluating expression of ESR1 (B), PGR (C), and PTGS2 (D). P, passage and D, day of culture. Scale bar $=1000 \mu \mathrm{m}(\mathrm{A})$ and $100 \mu \mathrm{m}(\mathrm{B}, \mathrm{C}$ and $\mathrm{D})$. 
organoid culture, and the equine organoids were cultured with the addition of penicillin/streptomycin, ITS, and SB202190. Primocin is an antimicrobial agent, which was substituted with penicillin and streptomycin for antimicrobial coverage for the equine organoids. R-spondin-1, a common supplement in organoid cultures (Clevers 2016, Boretto et al. 2017, Powell \& Behnke 2017), is linked to the Wnt signaling pathway (Kim et al. 2008), which is necessary for cell function, including in the equine endometrium (Atli et al. 2011). HGF is a growth factor that promotes proliferation and differentiation of epithelium and has been used in organoid cultures (Haslam et al. 2008, Sato \& Clevers 2015, Kaushik et al. 2018). For the mare, it was not critical to include these additional supplements in the culture medium, as we were able to consistently produce viable organoids in vitro in the absence of these factors. However, addition of R-spondin-1 and/or HGF may increase growth rate or hormone-responsiveness of organoids, as reported in human endometrial culture (Turco et al. 2017), and could be an area of future research.

This is the first report of endometrial organoid production from both fresh and frozen-thawed tissue. Endometrial explants were cryopreserved using slow cooling $\left(\sim 1^{\circ} \mathrm{C} / \mathrm{min}\right)$ in the presence of $10 \%$ dimethyl sulfoxide (DMSO) as previously described (Thompson et al. 2019, 2020). Cryopreservation conditions optimized for the domestic mare also were suitable for the preservation of Przewalski's horse endometrial tissue. The ability to cryopreserve equine endometrial biopsies not only allows for year-round reproductive studies using in vitro approaches, a historical challenge in mares due to seasonally anestrous cyclicity, but also permits systematic collection and banking of endometrial biopsies from both domestic and endangered equids. Additionally, utilization of frozen-thawed endometrial tissue may mitigate seasonal influences on data generated with tissues derived from different times of the year, which is particularly important for species that experience seasonal reproduction.

Organoids derived from both fresh and frozen-thawed endometrial tissue from domestic mares responded to exogenous hormone stimulation with changes in gene expression. While $\mathrm{CDH} 1$, the gene marker for cell adhesion, was reduced in some of the organoids derived from frozen-thawed tissue, cell proliferation, as indicated by MKI67 mRNA (Sinn et al. 2017), was not altered among any of the treatment groups in organoids derived from either fresh or frozen-thawed tissue. Estradiol-17 $\beta$ in culture media (both $\mathrm{E}_{2}$ and $\mathrm{E}_{2} / \mathrm{P}_{4}$ ) reduced expression of ESR1 in both fresh and frozen-thawed tissue-derived organoids. Additionally, organoids derived from fresh tissues exposed to $E_{2}$ supplemented culture medium displayed elevated $P G R$ expression. These results demonstrate the ability of organoids to respond to exogenous steroid hormone treatment with corresponding changes in gene expression. In mares, estrogen and progesterone receptor protein and mRNA have been reported to increase during estrus and decrease during diestrus (Hartt et al. 2005), though another report indicated that PGR expression was unaffected between estrus and diestrus (Silva et al. 2014). Although we expected ESR1 and PGR to increase in organoids exposed to $E_{2}$ treatments and to decrease in $E_{2} / P_{4}$ and $P_{4}$ treatments, our results failed to support this prediction. This phenomenon may be due to the lack of feedback mechanisms that operate in vivo but are absent in the in vitro system, such as the absence of endometrial stromal cells and components of the hypothalamic-pituitary-gonadal axis, or variation among donors, which might have influenced our results and warrant additional studies. Furthermore, as the domestic mares utilized here were research mares that are often donated to a university, age, breed, and parity can be quite variable, which could have affected the outcome though all mares were considered reproductively sound by a veterinarian. We controlled for grade of uterine inflammation and fibrosis (Kenney-Doig I or Ila), general stage of the estrous cycle (estrus), and month of sample collection (August), but exact day of estrus (estrus is 4-7 days in length) was not controlled. To our knowledge, no reports have evaluated ESR1 and PGR gene expression of equine endometrial monolayer cell cultures in vitro, though immunohistochemical expression of ESR1 and PGR did not change in response to exogenous hormone treatments in cell cultures of equine endometrial stromal and epithelial cells separated by semipermeable membrane well inserts (Lapko et al. 2017).

Additionally, we evaluated PTGS2, PGES, and OXTR gene expression in response to treatment with two concentrations of oxytocin $\left(10^{-5} \mathrm{M}\right.$ and $\left.10^{-6} \mathrm{M}\right)$ to evaluate cellular function. Previous reports indicate that prostaglandin production in response to oxytocin treatment is a reliable approach to determine if cultured endometrial cells function physiologically (Takahashi et al. 2001, Szóstek et al. 2012a). In the present study, PTGS2 was reduced in frozen-thawed tissue-derived organoids when exposed to C/OT-5 but elevated in fresh tissue-derived organoids when treated with $\mathrm{C} /$ OT-6. Organoids displayed higher levels (expression) of PGES in both fresh and frozen-thawed derived tissue organoids when treated with C/OT-6. Lastly, OXTR was reduced in fresh-tissue-derived organoids treated with C/OT-5. Previous studies also have shown that $\mathrm{PGE}_{2}$ increases in response to oxytocin treatment during both the follicular phase and luteal phase in vivo (Galvão et al. 2013), and $\mathrm{PGE}_{2}$ production increases in equine endometrial stromal and epithelial monolayer cell cultures when incubated in the presence of $10^{-7} \mathrm{M}$ oxytocin (Szóstek et al. 2014). While the prostaglandin synthase fold changes reported here are lower than those reported in the mare monolayer culture (Szóstek et al. 2014), this could be due to the structural and functional differences between the monolayer and organoid culture models. In a monolayer, the exogenous 
hormones in the culture media are in direct contact with every cell, while organoids are 3D and embedded within Matrigel, probably limiting hormone diffusion through the Matrigel and restricting direct cellular contact to only the exterior of the organoids. Furthermore, fresh and frozen-thawed tissue-derived organoids showed a varying response in gene expression fold change, particularly with respect to PTGS2 and OXTR. While the overall generation of the organoids, protein expression, and mucin production did not appear to be affected by origin of the tissue (fresh vs frozen-thawed), further optimization may be required to ensure that frozenthawed tissue-derived organoids express appropriate changes in gene expression in response to exogenous hormones. While the prostaglandin synthase and OXTR gene expression was variable in this report, the organoids responded by stimulating the prostaglandin synthesis cascade in response to oxytocin treatment after culture.

An important finding is that while the organoid model has significant advantages over the currently available cell culture models for mares, some drawbacks are evident. First, the organoid model system contains only the glandular epithelium. These glandular epithelial cells are important because they are responsible for essential secretory activity of the uterus. However, endometrial stromal cells respond differently to hormonal stimuli than epithelial cells and still contribute to the normal function of and signaling in the equine endometrium (Aupperle et al. 2000). Secondly, Matrigel has been used for many cell culture models, but the 3D extracellular matrix does contain proteins that may interact with the endometrial cells and interfere with normal signaling processes or diffusion of exogenous substances (compared to direct contact of exogenous substances in culture media with monolayer and explant cultures) and varies in composition among batches (Langhans 2018, Aisenbrey \& Murphy 2020, Wiwatpanit et al. 2020). Lastly, we describe endometrial organoids oriented with the apical portion of the cells to the interior of the cellular clusters. This can be advantageous to create a localized site to contain all cellular secretions; however, this orientation may not be ideal for evaluating interactions to certain exogenous substances, though orientation did not appear to affect ability to respond to exogenous hormone treatments. Future studies could explore reversing the polarity of the organoids so that the apical portion of the cell is located on the exterior of the cellular cluster.

Przewalski's horses, endangered equids native to Asia, were once extinct in the wild (King et al. 2015). After diligent efforts by captive breeding programs, they are now considered endangered by the IUCN Red List of Threatened Species (King et al. 2015) with 2,000 individuals worldwide. Reproduction in endangered equids is similar to domestic horses, but not identical. For example, length of the reproductive (estrous) cycle in Przewalski's horses is slightly longer ( $\sim 25$ days) than the domestic horse ( 21 to 22 days), though individual variation is common in both subspecies (Collins et al. 2012). Reproductive research in Przewalski's horses has focused on assisted reproductive technologies (Monfort et al. 1991, 1994, Collins et al. 2014, Pukazhenthi et al. 2014), but thorough evaluation of the normal reproductive mechanisms associated with the uterus has not occurred. This wild equid has been maintained in captivity and can be handled for reproductive evaluation with the aid of a specialized handling systems, however, length and frequency of handling are much more restricted than in domestic horses. Therefore, minimally invasive methods of evaluating reproduction in nondomestic equids is critical. While our sample size for Przewalski's mares was restricted $(n=3)$ due to a limited number of individuals in captive populations in addition to challenges associated with handling, we demonstrated our ability to generate long-term growth of endometrial organoids from this endangered species. In contrast to domestic mares, no significant gene expression changes occurred in response to hormone treatments, likely due to the low sample size, but we demonstrated protein expression of ESR1, PGR, and PTGS2 through immunohistochemistry in the organoids. Although Przewalski's horses diverged evolutionarily from the domestic horse thousands of years ago (Der Sarkissian et al. 2015), the mechanisms enabling formation of endometrial organoids appear to be conserved between the domestic mare and the Przewalski's horse.

In conclusion, this is the first report of equine endometrial organoid generation and long-term culture. The organoid cultures can be maintained long-term while retaining the ability to respond to hormonal stimuli (at least in the domestic mare), which overcomes the two short-comings associated with the traditional equine endometrial explant and monolayer cell cultures. This is also the first report of endometrial organoids developed from frozen-thawed tissue in any species. Finally, this is the first report of in vitro culture to assess reproduction of endangered Przewalski's horses. This novel method of culturing equine endometrium in vitro may lead to improved in vitro evaluation of normal reproductive physiology, pathological conditions, and potential therapies for uterine diseases in both domestic and endangered equids.

\section{Declaration of interest}

The authors declare that there is no conflict of interest that could be perceived as prejudicing the impartiality of the research reported.

\section{Funding}

This research was supported by funding from the American Association of Equine Practitioners Foundation, Mr Mike Baudhuin, and the Albert G Clay Endowment at the University of Kentucky. 


\section{Author contribution statement}

R E T and B S P designed the study and obtained funding. $R$ E T, A K J, P D, T M P, B A B and B S P participated in sample collections. R E T conducted all laboratory experiments. R E $\mathrm{T}$ and B S P conducted data analysis. M Y T, G J B and B K $W$ provided guidance in development of methodology and experimental design. C P assisted with histological assessment of samples. R E T and B S P wrote the original draft of the manuscript, and all co-authors reviewed and edited final version of the manuscript.

\section{Acknowledgements}

The authors express their gratitude for assistance with sample collection to Dr Jessica Klabnik and to Dr Julie Lamy, Dr Jennifer Nagashima, Dr Marcia Ferraz, Dr Megan Brown, and Dr Nucharin Songsasen for troubleshooting various assays. The authors also thank the entire ungulate animal management team, including Dolores Reed, Tara Buk, Morgan Vance, Arielle Harwood, Christopher Matthews, and Lawrence Layman, and the veterinary staff, including Dr Kelly Helmick, Dr Kristi Delaski, Lisa Ware, and Julia Jones, at SCBI for their assistance with anesthesia of Przewalski's horses for biopsy collection.

\section{References}

Aisenbrey EA \& Murphy WL 2020 Synthetic alternatives to Matrigel. Nature Reviews Materials 5 539-551. (https://doi.org/10.1038/s41578020-0199-8)

Annandale A, Stroehle RM, Schulman ML, Sibeko-Matjila KP, Fosgate GT, Handler J, Vemming DC \& Clift SJ 2018 Influence of cycle stage, age and endometrial biopsy score on oxytocin receptor distribution and gene expression in the cervix and uterus of non-pregnant mares. Theriogenology 120 1-9. (https://doi.org/10.1016/j.theriogenology.2018.07.013)

Atli MO, Guzeloglu A \& Dinc DA 2011 Expression of wingless type (WNT) genes and their antagonists at mRNA levels in equine endometrium during the estrous cycle and early pregnancy. Animal Reproduction Science 125 94-102. (https://doi.org/10.1016/j.anireprosci.2011.04.001)

Aupperle H, Ozgen SSchoon HA, Schoon D, Hoppen HO, Sieme H \& Tannapfel A 2000 Cyclical endometrial steroid hormone receptor expression and proliferation intensity in the mare. Equine Veterinary Journal 32 228-232. (https://doi.org/10.2746/042516400776563554)

Boretto M, Cox B, Noben M, Hendriks N, Fassbender A, Roose H, Amant F, Timmerman D, Tomassetti C, Vanhie A et al. 2017 Development of organoids from mouse and human endometrium showing endometrial epithelium physiology and long-term expandability. Development 144 1775-1786. (https://doi.org/10.1242/dev.148478)

Clevers H 2016 Modeling development and disease with organoids. Cell 165 1586-1597. (https://doi.org/10.1016/j.cell.2016.05.082)

Collins CW, Songsasen NS, Vick MM, Wolfe BA, Weiss RB, Keefer CL \& Monfort SL 2012 Abnormal reproductive patterns in Przewalski's mares are associated with a loss in gene diversity. Biology of Reproduction $\mathbf{8 6}$ 28. (https://doi.org/10.1095/biolreprod.111.092676)

Collins CW, Monfort SL, Vick MM, Wolfe BA, Weiss RB, Keefer CL \& Songsasen N 2014 Oral and injectable synthetic progestagens effectively manipulate the estrous cycle in the Przewalski's Horse (Equus ferus przewalskii). Animal Reproduction Science 148 42-52. (https://doi. org/10.1016/j.anireprosci.2014.03.018)

Collins A, Miles GJ, Wood J, MacFarlane M, Pritchard C \& Moss E 2020 Patient-derived explants, xenografts and organoids: 3-dimensional patient-relevant pre-clinical models in endometrial cancer. Gynecologic Oncology 156 251-259. (https://doi.org/10.1016/j.ygyno.2019.11.020)

Der Sarkissian C, Ermini L, Schubert M, Yang M, Librado P, Fumagalli M, Jónsson H, Bar-Gal G, Albrechtsen A, Vieira F et al. 2015 Evolutionary genomics and conservation of the endangered Przewalski's Horse. Current Biology 25 2577-2583. (https://doi.org/10.1016/j.cub.2015.08.032)
Fitzgerald HC, Dhakal P, Behura SK, Schust DJ \& Spencer TE 2019 Selfrenewing endometrial epithelial organoids of the human uterus. PNAS 116 23132-23142. (https://doi.org/10.1073/pnas.1915389116)

Galvão A, Valente L, Skarzynski DJ, Szóstek A, Piotrowska-Tomala K, Rebordão MR, Mateus L \& Ferreira-Dias G 2013 Effect of cytokines and ovarian steroids on equine endometrial function: an in vitro study. Reproduction, Fertility, and Development 25 985-997. (https://doi. org/10.1071/RD12153)

Garner DL \& Johnson LA 1995 Viability assessment of mammalian sperm using SYBR-14 and propidium iodide. Biology of Reproduction $\mathbf{5 3}$ 276-284. (https://doi.org/10.1095/biolreprod53.2.276)

Hartt LS, Carling SJ, Joyce MM, Johnson GA, Vanderwall DK \& Ott TL 2005 Temporal and spatial associations of oestrogen receptor alpha and progesterone receptor in the endometrium of cyclic and early pregnant mares. Reproduction 130 241-250. (https://doi.org/10.1530/rep.1.00596)

Haslam SZ, Drolet A, Smith K, Tan M \& Aupperlee M 2008 Progestinregulated luminal cell and myoepithelial cell-specific responses in mammary organoid culture. Endocrinology 149 2098-2107. (https://doi. org/10.1210/en.2007-1398)

Huang B, Li T, Alonso-Gonzalez L, Gorre R, Keatley S, Green A, Turner P, Kallingappa PK, Verma V \& Oback B 2011 A virus-free poly-promoter vector induces pluripotency in quiescent bovine cells under chemically defined conditions of dual kinase inhibition. PLOS ONE 6 e24501. (https://doi.org/10.1371/journal.pone.0024501)

Huch M, Dorrell C, Boj SF, Van Es JH, Li VS, Van De Wetering M, Sato T, Hamer K, Sasaki N, Finegold MJ et al. 2013 In vitro expansion of single Lgr5+ liver stem cells induced by Wnt-driven regeneration. Nature 494 247-250. (https://doi.org/10.1038/nature11826)

Kalpokas I, Perdigón F, Rivero R, Talmon M, Sartore I \& Viñoles C 2010 Effect of a povidone-iodine intrauterine infusion on progesterone levels and endometrial steroid receptor expression in mares. Acta Veterinaria Scandinavica 52 66. (https://doi.org/10.1186/1751-0147-52-66)

Karthaus WR, laquinta PJ, Drost J, Gracanin A, Van Boxtel R, Wongvipat J, Dowling CM, Gao D, Begthel H, Sachs N et al. 2014 Identification of multipotent luminal progenitor cells in human prostate organoid cultures. Cell 159 163-175. (https://doi.org/10.1016/j.cell.2014.08.017)

Kaushik G, Ponnusamy MP \& Batra SK 2018 Concise review: current status of three-dimensional organoids as preclinical models. Stem Cells $\mathbf{3 6}$ 1329-1340. (https://doi.org/10.1002/stem.2852)

Keith L, Ball BA, Scoggin K, Esteller-Vico A, Woodward EM, Troedsson MH \& Squires EL 2013 Diestrus administration of oxytocin prolongs luteal maintenance and reduces plasma PGFM concentrations and endometrial COX-2 expression in mares. Theriogenology 79 616-624. (https://doi. org/10.1016/j.theriogenology.2012.11.015)

Kenney RM \& Doig PA 1986 Equine endometrial biopsy. In Current Therapy in Theriogenology, pp. 723-729. Ed. DA Morrow. Philadelphia: Saunders WB.

Kessler M, Hoffmann K, Brinkmann V, Thieck O, Jackisch S, Toelle B, Berger H, Mollenkopf HJ, Mangler M, Sehouli J et al. 2015 The Notch and Wnt pathways regulate stemness and differentiation in human Fallopian tube organoids. Nature Communications 6 8989. (https://doi. org/10.1038/ncomms9989)

Kim KA, Wagle M, Tran K, Zhan X, Dixon MA, Liu S, Gros D, Korver W, Yonkovich S, Tomasevic N et al. 2008 R-spondin family members regulate the Wnt pathway by a common mechanism. Molecular Biology of the Cell 19 2588-2596. (https://doi.org/10.1091/mbc.e08-02-0187)

King SR, Boyd L, Zimmermann W \& Kendall BE 2015 Equus ferus. IUCN RED List of Threatened Species 2015 e.T41763A97204950. (https://doi. org/10.2305/IUCN.UK.2015-2.RLTS.T41763A45172856.en)

Koyanagi M, Takahashi J, Arakawa Y, Doi D, Fukuda H, Hayashi H, Narumiya S \& Hashimoto $\mathbf{N} 2008$ Inhibition of the Rho/ROCK pathway reduces apoptosis during transplantation of embryonic stem cell-derived neural precursors. Journal of Neuroscience Research 86 270-280. (https://doi.org/10.1002/jnr.21502)

Lancaster MA, Renner M, Martin CA, Wenzel D, Bicknell LS, Hurles ME, Homfray T, Penninger JM, Jackson AP \& Knoblich JA 2013 Cerebral organoids model human brain development and microcephaly. Nature 501 373-379. (https://doi.org/10.1038/nature12517)

Langhans SA 2018 Three-dimensional in vitro cell culture models in drug discovery and drug repositioning. Frontiers in Pharmacology 9 6. (https:// doi.org/10.3389/fphar.2018.00006)

Lapko L, Böttcher D, Theuß T, Klug J \& Schoon HA 2017 Establishment and characterization of a coculture system of equine endometrial epithelial 
and stromal cells. Reproduction in Domestic Animals 52 327-334. (https://doi.org/10.1111/rda.12915)

Li X, Krawetz R, Liu S, Meng G \& Rancourt DE 2009 ROCK inhibitor improves survival of cryopreserved serum/feeder-free single human embryonic stem cells. Human Reproduction 24 580-589. (https://doi. org/10.1093/humrep/den404)

Livak KJ \& Schmittgen TD 2001 Analysis of relative gene expression data using real-time quantitative PCR and the $2-\Delta \Delta C T$ method. Methods 25 402-408. (https://doi.org/10.1006/meth.2001.1262)

Monfort SL, Arthur NP \& Wildt DE 1991 Monitoring ovarian function and pregnancy by evaluating excretion of urinary oestrogen conjugates in semi-free-ranging Przewalski's horses (Equus przewalskii). Journal of Reproduction and Fertility 91 155-164. (https://doi.org/10.1530/ jrf.0.0910155)

Monfort SL, Arthur NP \& Wildt DE 1994 Reproduction in the Przewalski's horse. In Przewalski's Horse, pp. 173-193. Eds L Boyd \& KA Houpt. Albany: State University of New York.

Perrini C, Strillacci MG, Bagnato A, Esposti P, Marini MG, Corradetti B, Bizzaro D, Idda A, Ledda S, Capra E et al. 2016 Microvesicles secreted from equine amniotic-derived cells and their potential role in reducing inflammation in endometrial cells in an in-vitro model. Stem Cell Research and Therapy 7 169. (https://doi.org/10.1186/s13287-016-0429-6)

Powell RH \& Behnke MS 2017 WRN conditioned media is sufficient for in vitro propagation of intestinal organoids from large farm and small companion animals. Biology Open 6 698-705. (https://doi.org/10.1242/ bio.021717)

Pukazhenthi BS, Johnson A, Guthrie HD, Songsasen N, Padilla LR, Wolfe BA, da Silva MC, Alvarenga MA \& Wildt DE 2014 Improved sperm cryosurvival in diluents containing amides versus glycerol in the Przewalski's horse (Equus ferus przewalskii). Cryobiology 68 205-214. (https://doi.org/10.1016/j.cryobiol.2014.01.013)

Pukazhenthi BS, Nagashima J, Travis AJ, Costa GM, Escobar EN, França LR \& Wildt DE 2015 Slow freezing, but not vitrification supports complete spermatogenesis in cryopreserved, neonatal sheep testicular xenografts. PLoS ONE 10 e0123957. (https://doi.org/10.1371/journal. pone.0123957)

R Core Team 2014 R: A Language and Environment for Statistical Computing, Vol. 2013. Vienna, Austria: R Foundation for Statistical Computing, .3900051-07-0

Rebordão MR, Galvão A, Pinto-Bravo P, Pinheiro J, Gamboa S, Silva E, Mateus L \& Ferreira-Dias G 2017 Endometrial prostaglandin synthases, ovarian steroids, and oxytocin receptors in mares with oxytocininduced luteal maintenance. Theriogenology 87 193-204. (https://doi. org/10.1016/j.theriogenology.2016.08.028)

Samuel CA, Ricketts SW, Rossdale PD, Steven DH \&Thurley KW 1979 Scanning electron microscope studies of the endometrium of the cyclic mare. Journal of Reproduction and Fertility: Supplement 27 287-292.

Santos VG, Castro T, Bettencourt EM \& Ginther OJ 2015 Oxytocin induction of pulses of a prostaglandin metabolite and luteolysis in mares. Theriogenology 83 730-738. (https://doi.org/10.1016/j. theriogenology.2014.11.006)

Sato T \& Clevers H 2015 SnapShot: growing organoids from stem cells. Cell 161 1700.e1-1700.e1. (https://doi.org/10.1016/j.cell.2015.06.028)

Sato T, Stange DE, Ferrante M, Vries RG, Van Es JH, Van Den Brink S, Van Houdt WJ, Pronk A, Van Gorp J, Siersema PD et al. 2011 Longterm expansion of epithelial organoids from human colon, adenoma, adenocarcinoma, and Barrett's epithelium. Gastroenterology 141 1762-1772. (https://doi.org/10.1053/j.gastro.2011.07.050)

Schwinghamer R, Massolo A, Knight C \& Klein C 2018 Equine endometrial explants undergo significant degenerative changes in culture. Anatomical Record 301 148-153. (https://doi.org/10.1002/ar.23701)

Sharp DC, Thatcher MJ, Salute ME \& Fuchs AR 1997 Relationship between endometrial oxytocin receptors and oxytocin-induced prostaglandin F2 $\alpha$ release during the oestrous cycle and early pregnancy in pony mares. Journal of Reproduction and Fertility 109 137-144. (https://doi. org/10.1530/jrf.0.1090137)

Silva ES, Scoggin KE, Canisso IF, Troedsson MH, Squires EL \& Ball BA 2014 Expression of receptors for ovarian steroids and prostaglandin E2 in the endometrium and myometrium of mares during estrus, diestrus and early pregnancy. Animal Reproduction Science 151 169-181. (https:// doi.org/10.1016/j.anireprosci.2014.11.001)
Sinn HP, Schneeweiss A, Keller M, Schlombs K, Laible M, Seitz J, Lakis S, Veltrup E, Altevogt P, Eidt S et al. 2017 Comparison of immunohistochemistry with PCR for assessment of ER, PR, and Ki-67 and prediction of pathological complete response in breast cancer. $B M C$ Cancer 17 124. (https://doi.org/10.1186/s12885-017-3111-1)

Starbuck GR, Stout TA, Lamming GE, Allen WR \& Flint AP 1998 Endometrial oxytocin receptor and uterine prostaglandin secretion in mares during the oestrous cycle and early pregnancy. Journal of Reproduction and Fertility 113 173-179. (https://doi.org/10.1530/jrf.0.1130173)

Stout TA, Lamming GE \& Allen WR 2000 Oxytocin and its endometrial receptor are integral to luteolysis in the cycling mare. Journal of Reproduction and Fertility: Supplement $\mathbf{5 6}$ 281-287.

Szóstek AZ, Siemieniuch MJ, Galvão AM, Lukasik K, Zieba D, FerreiraDias GM \& Skarzynski DJ 2012a Effects of cell storage and passage on basal and oxytocin-regulated prostaglandin secretion by equine endometrial epithelial and stromal cells. Theriogenology 77 1698-1708. (https://doi.org/10.1016/j.theriogenology.2011.12.015)

Szóstek AZ, Siemieniuch MJ, Lukasik K, Galvao AM, Ferreira-Dias GM \& Skarzynski DJ 2012b mRNA transcription of prostaglandin synthases and their products in the equine endometrium in the course of fibrosis. Theriogenology 78 768-776. (https://doi.org/10.1016/j. theriogenology.2012.03.024)

Szóstek AZ, Galvao AM, Ferreira-Dias GM \& Skarzynski DJ 2014 Ovarian steroids affect prostaglandin production in equine endometrial cells in vitro. Journal of Endocrinology 220 263-276. (https://doi.org/10.1530/ JOE-13-0185)

Takahashi H, Iga K, Sato T, Takahashi M \& Okano A 2001 Isolation and culture of bovine endometrial epithelial cells in a serum-free culture system. Journal of Reproduction and Development 47 181-187. (https:// doi.org/10.1262/jrd.47.181)

Thompson RE, Johnson AK, Prado TM, Premanandan C, Brown ME, Whitlock BK \& Pukazhenthi BS 2019 Dimethyl sulfoxide maintains structure and function of cryopreserved equine endometrial explants. Cryobiology $91 \quad 90-96 . \quad$ (https://doi.org/10.1016/j. cryobiol.2019.10.006)

Thompson RE, Brown ME, Helmick K, Whitlock BK \& Pukazhenthi BS 2020 Persian onager (Equus hemionus onager) endometrial explant cryopreservation and in vitro culture. Animal Reproduction Science $\mathbf{2 1 7}$ 106459. (https://doi.org/10.1016/j.anireprosci.2020.106459)

Turco MY, Gardner L, Hughes J, Cindrova-Davies T, Gomez MJ, Farrell L, Hollinshead M, Marsh SGE, Brosens JJ, Critchley HO et al. 2017 Longterm, hormone-responsive organoid cultures of human endometrium in a chemically defined medium. Nature Cell Biology 19 568-577. (https:// doi.org/10.1038/ncb3516)

Watanabe K, Ueno M, Kamiya D, Nishiyama A, Matsumura M, Wataya T, Takahashi JB, Nishikawa S, Nishikawa SI, Muguruma K et al. 2007 A ROCK inhibitor permits survival of dissociated human embryonic stem cells. Nature Biotechnology 25 681-686. (https://doi.org/10.1038/ nbt1310)

Wiwatpanit T, Murphy AR, Lu Z, Urbanek M, Burdette JE, Woodruff TK \& Kim JJ 2020 Scaffold-free endometrial organoids respond to excess androgens associated with polycystic ovarian syndrome. Journal of Clinical Endocrinology and Metabolism 105 769-780. (https://doi. org/10.1210/clinem/dgz100)

Xie Y, Park ES, Xiang D \& Li Z 2018 Long-term organoid culture reveals enrichment of organoid-forming epithelial cells in the fimbrial portion of mouse fallopian tube. Stem Cell Research 32 51-60. (https://doi. org/10.1016/j.scr.2018.08.021)

Ying QL, Wray J, Nichols J, Batlle-Morera L, Doble B, Woodgett J, Cohen P \& Smith A 2008 The ground state of embryonic stem cell self-renewal. Nature 453 519-523. (https://doi.org/10.1038/nature06968)

Received 14 May 2020

First decision 8 July 2020

Revised Manuscript received 27 July 2020

Accepted 1 September 2020 